\title{
Barack Obama, the War on Terrorism and the US Hegemony
}

\section{Gökhan Telatar*}

\begin{abstract}
The war on terrorism constituted a vision oriented in reconstructing American hegemony by consisting of elements such that combat against terrorist organizations, democracy promotion and elimination of mass destruction weapons threat after the September 11 terrorist attacks. Barack Obama severely criticized George W. Bush administration's policies concerning the war on terrorism. Thus, he has intended to strengthen the American hegemony by maintaining this vision through more mentalist policies. The present article analyzes the position of vision for war on terrorism within the Obama administration's foreign policy. In order to achieve this, the Obama administration's policies concerning combating against terrorist organizations, democracy promotion and prevention of mass destruction weapons constitute elements of the vision for war on terrorism will be investigated. Finally, the article revealed the degree of conformity of the Obama administration's foreign policy with the war on terrorism initiated by the Bush administration and analyzed effects of the Obama administration's foreign policy on American hegemony.
\end{abstract}

Key Words: Barack Obama; American hegemony; September 11; War on terrorism; Democracy promotion; Weapons of mass destruction.

\footnotetext{
* Abant Izzet Baysal University, Faculty of Economic, telatargokhan@ @otmail.com
} 
Gökhan Telatar

\section{Introduction}

American hegemony was constructed on participation of various countries, which gathered around a common interest as a block against the communism threat emerged after the World War II, and on their recognizance of the United States as hegemon. A hegemonic order established in

| 42 this way has gained legitimacy because its structure was set to satisfy not only US interests but also interests of subject countries those were loyal to this system at varying levels. ${ }^{1}$ Upon conclusion of the Cold War, the communism is not considered the main threat toward Western countries anymore, thus, the common interest that lies under the foundation of the American hegemony disappeared. Since the need for Washington decreased for maintenance of the international order, it was more difficult for the US administration to obtain other countries' consent to adopt the hegemon role of the United States. ${ }^{2}$

As stated by Antonio Gramsci, the supremacy of a group is manifested in both 'domination' and 'intellectual and moral leadership'. In Gramsci's theory, domination is the exercise of coercion over other groups. Hegemony is the exercise of intellectual and moral leadership over other groups. ${ }^{3}$ Gramsci's recognition of the concept of hegemony is based on an 'equilibrium constituted by a combination of force and consent which are balanced in varying proportions, without force prevailing too greatly over consent' ${ }^{4}$ Inspired by Gramsci's definition of hegemony, Robert Cox states that a hegemon actor needs to have power, consents of other states are required as well. ${ }^{5}$ According to Cox, hegemony is an order that serves interests of hegemon state and various states in its periphery, and it is legitimized by these states. In order to obtain consents of states and to ensure legitimacy of the order, the hegemon is required to associate its interests with interests of other states, and thus, other states define their interests in a harmony with the hegemon's interests. ${ }^{6}$ In case disruption of harmony between interests of hegemon and other states as a result of losing common interests, legitimacy source of a hegemonic order is then be disappeared, it would be more troublesome for a hegemon actor to obtain consents of other states and its order would ultimately experience a crisis. ${ }^{7}$ In that case, it is expected from hegemon to make an effort to achieve consents of other states once more in order to gain legitimacy for its hegemony; in other words, it is required to reconstruct its hegemony.

1990s were such a period for the American hegemony. In the sequel of disruption to the common interest regarding containment framework of communism, the US hegemony's source of ideological legitimacy was started to be questioned. This situation complicated to achieve consents of other states by the United States. Therefore, the United States experienced difficulty in gaining support from its allies and international society in many of foreign policy-related initiatives in 90s. Consequently, this result affected success of the foreign policy followed by the Washington.

A search for new vision based on common interest to reconstruct the American hegemony dominated the US foreign policy history in 1990s. ${ }^{8}$ The terrorism threat has taken attention across the world in terms of maintaining international peace and security after destructive September 11 attacks against the United States. The United States attempted to create a common threat perception by emphasizing that this threat was against the whole world. Numbers of countries around the world face with the terrorism threat seriously. Moreover, numbers of anti-democratic countries consider domestic opposition movements and uprisings in context of terrorism. Thus, terrorism is within threat perception of many countries around the world. Therefore, the effort to create common interest through the global war on terror that was commenced by the US in the post-September 11 period has significantly succeeded. The US administration associated its interests with interests of other states under terrorism threat and tried to gain support from these countries by setting off a global war against terrorism. Numerous states has presented their support to the United States in its war on terror and defined their interests in the same line with the American interests by including this subject in their foreign policy agendas. Furthermore, activities in related with the war on terrorism have gone far by the policy followed and oriented on terrorist organizations; and it included dimensions of democracy promotion and prevention of 
weapons of mass destruction (WMD) threat, ${ }^{9}$ and thus, it emerged as a vision that enabled reconstruction of the American hegemony.

Hence, the United States found opportunity to set off political and military campaigns, such as wars in Afghanistan and Iraq, to establish military bases, to gain control over oil reserves, and to manage focus of international society along with the US interests under the so-called war on terrorism. The United States also re-structured the national security system, made new arrangements in legislation system, and created new security strategies. These initiatives were serving purpose of reconstruction of the American hegemony. ${ }^{10}$ Therefore, the Bush administration saw war on terrorism as a vision that strengthens both in terms of force and consent dimensions of the American hegemony. Thus, the vision for war on terrorism has taken a major place in the American foreign policy.

In order to ensure that the American public adopts war on terrorism, it was emphasized that terrorists are targeting American unity, freedom and democracy. The association of the war on terrorism with the American values (such as democracy, personal liberty, human rights, and rule of law $)^{11}$ and identity has been one of the elements that enables war on terrorism to become such a comprehensive foreign policy vision that it can fill the gap left behind the struggle with communism. According to David Campbell, foreign policy practices have been influential in the processes of both formation and maintaining of American national identity. Additionally, Campbell argues that identity was established in conjunction with differences, and that it ensures its safety by drawing ideological borders concerning what is right or what is wrong in terms of values/ideals descripting an identity. ${ }^{12}$ American national identity has been maintained by means of foreign policy executed against 'others' who were produced by marginalization of terrorism emphasized that it is targeting existence of American people and their values, of pro-terrorism states and radical Islamic ideology during post-September 11 period.

Since the war on terrorism, as an ideological legitimacy foundation of the American hegemony, was a comprehensive vision shown as the candidate to fill up the gap left by the struggle with communism, Barack Obama was expected to follow this vision after he took over the presidency in 2009 as well. However, President Obama came to power by criticizing George W. Bush administration's policies on the war on terrorism. Based on this paradox, this article analyzes position of war on terrorism in Obama administration's foreign policy. First, the approach of the Obama administration toward vision for war on terrorism was exhibited. Then, policies of the Obama administration on basic elements, which constitute vision for war on terrorism, ${ }^{13}$ namely, combat against the terrorist organizations, democracy promotion, and prevention of WMD were described. It was claimed that Obama puts emphasis on basic elements of war on terrorism in its foreign policy. However, as he criticized Bush administration's policies concerning this vision, he tried to follow more rational policies to strengthen American hegemony, which was damaged by the policies of the Bush Administration. Therefore, the article's subject is limited with analysis of the approach and policies of the Obama administration concerning the war on terrorism and the elements composing this vision. Investigation of other policies followed by the Obama administration to strengthen the American hegemony is out of interest of this article.

\section{Approach of the Obama Administration toward the Vision for War on Terrorism}

Even though Obama seriously criticized the policies of the Bush period within the war on terrorism framework, he has not abandoned this vision. It is not true to claim that the Obama administration's foreign policy was structured totally based on vision for war on terrorism. However their foreign policy place significant importance on basic elements of this vision. Because the Bush administration was not successful satisfactorily on the essential elements of war on terrorism, combating against terror organizations, democracy promotion and prevention of WMD. President Obama was oriented on being successful on these subjects by following more 
effective policies. Furthermore, it was hard to insist on abandoning the war on terrorism since this has been a comprehensive vision oriented on reconstructing American hegemony and this has been important part of the American political life after it was associated with the American national identity.

Obama adopted similar point of view with the Bush administration in terms of | 44 interpretation of the meaning of September 11 attacks, that terrorism was a vital threat directly targeting the United States, and it is required to fight with terrorists all over the world. President Obama associated war on terrorism with the American values and identity as well by emphasizing that they, as Americans, will not apologize for their way of life and their values were so strong that it is impossible to shatter them with these terrorist attacks. ${ }^{14}$ Moreover, Obama stated that American society was required to be awake against terrorism because terrorists do not only target their security, but also were trying to weaken their open social structure and their values. Obama underlined that upon September 11 attacks, as nation, they initiated a new chapter in their history to develop new strategies, to ensure security of the homeland, and to protect their values. ${ }^{15}$ The president also emphasized that they act under the guidance of their hope, unity and values, therefore, they, as a nation, will never be seized by the fear against terrorism and never retreat. ${ }^{16}$

In addition, the Obama administration did not underestimate the significance and position of the war on terrorism in reconstruction process of the American hegemony. On the contrary, they realized that the Bush administration dragged the American hegemony into deeper crisis through the policies within the framework of vision for war on terrorism aiming reconstruction of the American hegemony. Thus, the Obama administration has tried to restore the American hegemony by means of more rational policies. While Bush administration succeeded to collapse the enemy regimes within the short period, however, it was not easy to re-structure effective government bodies that operate smoothly. In spite of the costly Iraq war that sums over half a trillion dollar, American soldiers were still in active fight by 2009. ${ }^{17}$ The arguments about legitimacy of the war and human right violations in Abu Ghraib and Guantanamo placed a negative impression on the soft power of the United States. ${ }^{18}$ On the other hand, Al-Qaeda and Taliban have gained their strengths once more, which increased the pressure on the Hamid Karzai administration in Afghanistan, and committed violent attacks on the Pakistan border. ${ }^{19}$ These circumstances proved that strengths of the radical groups have deeper ground than the expected level. ${ }^{20}$ Therefore, the Washington administration was required to overhaul its strategies concerning Afghanistan and Pakistan.

Collapse of the enemy regimes in Afghanistan and Iraq did not confirm expectations of Bush administration concerning its deterrent effects on other anti-American regimes. Iran and North Korea continued their nuclear programs. Opening the military card on the table complicated solution of these issues even further. ${ }^{21}$ It was a challenging task to initiate nation building projects by promoting democracy (such as the Greater Middle East Initiative) in the failed or antidemocratic states and to exterminate the terror resources in the post September 11 period. Hence, the United States has gone beyond limits of its power within the framework of vision for war on terrorism, because it aimed to root out terror organizations and the states, which support these organizations and threat world with their WMD. ${ }^{22}$ In other words, unsuccessful conclusions of the policies followed by the Bush administration weakened the force dimension of the American hegemony.

The Bush administration's policies mentioned above primarily damaged the consent dimension of the American hegemony. The United States and the European countries, its most intimate allies, were deeply dissenting especially regarding Iraqi war in 2003 and military option against Iran. ${ }^{23}$ Majority of American allies were not eager to support unilateral and militaryoriented policies of the Bush administration. ${ }^{24}$ Moreover, global actors displeased by American hegemony, such as Russia and China, started to express their discomfort about many issue even louder. ${ }^{25}$ It was hard to overcome the issues faced by the US administration in an environment in which some states were in disfavor of the hegemonic position of the United States rather than adopting it, and in which the US administration was facing reaction from the international society 
in many areas of the foreign policy instead of having their consent. ${ }^{26}$ Therefore, American hegemony's faltering consent dimension affected its force dimension negatively.

After taking over such an inheritance, President Obama took an action to cease weakening pace in the American hegemony. In this regard, the administration removed the expression of 'war on terrorism', which has gained a negative sense because of the policies of the Bush administration, from the foreign policy rhetoric. ${ }^{27}$ The perception that the war on terrorism was indeed against Islam was hindering the Obama administration to make a fresh start with the Islamic world in terms of their relationships. Even though the Obama administration has dropped expression of 'war on terrorism', it has been loyal to the basic elements of vision for war on terrorism like the Bush administration. The reason for this, as stated earlier, was that war on terrorism has taken a major place in the American foreign policy and in American political life. Upon failure of the Bush administration's policies in related with the war on terrorism in order to relieve crisis of the US hegemony, the Obama administration tried to make an attempt to relieve crisis in hegemony likewise the Bush administration. Nevertheless, unlike the policies of the Bush administration, which cause the American hegemony loose more blood, the Obama administration aimed to execute the vision for war on terrorism through more rational policies. Furthermore, similar to Gramsci's opinion mentioned in previous pages, the Obama administration has strived to establish better balance between force and consent dimensions of the American hegemony within its policies. In other words, the Obama administration has tried to develop strength of the United States by bringing solution to the issues faced and to have consent of the international society, especially its close allies, for its hegemonic position.

\section{War on Terrorism Vision in the Foreign Policy of the Barack Obama Administration}

Concerning the Obama administration's priorities in foreign policy, they exhibit remarkable similarities with the Bush administration's vision for war on terrorism. President Obama determined WMD, rogue states cooperating with terrorist organizations, failed states, rising powers and global warming among threats of the $21^{\text {st }}$ century in one of his article published in $2007 .^{28}$ These threats (except the global warming) were also the ones oriented by the Bush administration and they were subjects within the vision for war on terrorism. The Bush administration first highlighted terrorist organizations, then, states supporting terrorists, threatening its neighbors and the world with their WMD, and oppressing their societies as threats against international peace and security in the post-September 11 period. The Bush administration was emphasizing that there is need to initiate an international struggle against these threats under the leadership of the United States, as it is hegemon. Therefore, the vision for war on terrorism was established on elements of 'combat against terrorist organizations', 'democracy promotion' and 'prevention of threat of WMD'. Accordingly, in the further sections, our study analyzes the Obama administration's policies concerning these three elements in order to reveal the degree of conformity of the Obama administration's foreign policy with the vision for war on terrorism initiated by the Bush administration and their effects on American hegemony.

\section{Policies for Combat against Terrorist Organizations}

\section{More Effective Combat against Terrorists}

Combat against terrorist organizations is the most important element since it is the subject enabling setting up a vision for war on terrorism. In spite of this function, its significance decreased because the Bush administration concentrated on Iraq after 2003. The United States has faced several failures in combat against terrorist organizations over the time. Taliban started to develop its control over Afghanistan after it gained power once more. While number of death American soldiers in the Afghanistan war was 155 in 2008, this number increased to 317 in 
2009. ${ }^{29}$ Al-Qaeda leader, Osama bin Laden has not been captured yet by that time. President Obama realized that these failures experienced during combat against terrorist organizations were affecting the US strength adversely and weakening its hegemony. If Al-Qaeda terrorism was such a great threat for both United States and other states that the United States underlined after the September 11 attacks, it would be a necessity for the United States to defeat this organization. As Robert Cox stated, in order to become hegemon, a state would have to found and protect a | 46 universal world order, which most other states could find compatible with their interests. ${ }^{30}$ Hegemon state has responsibilities associated with maintenance of international order and stability. In case Al-Qaeda launches a massive attack like the September 11 attacks against the United States or its allies, there would be an impression that United States is not able to defend both its own and its allies' security. The United States's capability to protect international security as a hegemon would be questioned.

Obama was of the opinion that combat against terrorist organizations must be conducted more carefully based on its core purpose. In this regard, since it was not possible to fight against all terrorist organizations operating at the global scale, Obama defended that the military operations against Al-Qaeda that organized September 11 attacks must be intensified so that appropriate conditions to withdraw American soldiers from Afghanistan by the end of 2014 can be obtained..$^{31}$ In two months just after the election of President Obama, the United States declared the strategy to follow in Afghanistan and Pakistan in 27 March, 2009. In this strategy, the target of the war carried out in Afghanistan was determined as 'to disrupt, dismantle and to defeat $\mathrm{Al}$ Qaeda in Afghanistan and Pakistan and to ensure that it will not return to these countries ever' ${ }^{32}$ in narrower angle than the Bush administration's strategy. ${ }^{33}$ Consequently, the Obama administration was in desire to establish a balance between the capacity of the United States and its initiatives taken at the international scope, and to prevent these initiatives to weaken its hegemonic strength.

As President Obama to criticize insufficient resources reserved for Afghanistan war by the Bush administration during the Iraqi War, he approved to send more than 50,000 soldiers to Afghanistan to fight against Al-Qaeda and Taliban and to train Afghan security forces. ${ }^{34}$ Additionally, since victory chance in the war against both Al-Qaeda and Taliban was quite insignificant, the most logical choice on the table was going negotiation with Taliban to create a consistent Afghanistan in which Taliban was included in the political life before withdrawal of American soldiers. ${ }^{35}$ The fact that while the Obama administration was seeking to start negotiations with Taliban, additional troops were on the way to Afghanistan was based on the thought that acquisitions in the military wing would have pushed Taliban to participate into political life. ${ }^{36}$

Al-Qaeda was not only active in Afghanistan territory, but also it was organized in Pakistan. The fragile political environment in Pakistan worried the Obama administration such that any chaos atmosphere that may arise in here would give advantage to Al-Qaeda, and nuclear weapons of Pakistan would be captured by this group. ${ }^{37}$ Therefore, the Obama administration embraced a holistic point of view toward the war against Al-Qaeda together with Afghanistan and Pakistan. Accordingly, the administration approved significant military and economic aid to Pakistan $^{38}$ and increased the number of drone attacks toward Al-Qaeda targets in Pakistan in order to destroy its organization across the country. ${ }^{39}$

According to all these efforts, it can be concluded that there was no an optimistic view regarding the future of Afghanistan although President Obama concentrated on war against AlQaeda once again and achieved success at certain level. Assassination of Al-Qaeda leader Osama bin Laden on 2 May 2011 that tarnished motivation of Al-Qaeda's members and supporters was an important achievement. ${ }^{40}$ Since other senior leaders and militants of the Al-Qaeda and Taliban were surviving, there were much more issues to resolve in Afghanistan. It is obvious that the war in Afghanistan, which has been the longest war in the history of the country even at this stage, would continue for a while. An intelligence report issued in the end of year 2013 stressed that AlQaida and Taliban could have increased their influence and all recent acquisitions of the United 
States could have lost in case an international force would not have deployed afterwards of withdrawal of American soldiers. ${ }^{41}$

Afghanistan's view from the military perspective leverages importance of the efforts, which encourage including Taliban into political process. Opening an office in Qatar that is one of the allies of the United States, in the end of 2011s, was indicating that the organization was in search of compromise with the Western world. Although stipulated conditions by the Taliban leaders, difficult to approve by the United States, reduced the chance for success in negotiations, ${ }^{42}$ some progresses achieved concerning the process of exchanging prisoners/hostages. This was promising in terms of resuming negotiations between the United States and Taliban, which was interrupted in $2012 .{ }^{43}$ Yet, there has not been a concrete result obtained yet concerning Taliban to cease violence and disconnect its ties with Al-Qaeda. Conclusively, the Obama administration that has attempted to prevent weakening the strength of the American hegemony due to experienced failures in combat against terrorist organizations has gained partial success in this area. It is not easy to say that the Obama administration has gained the aimed success completely in combat against terrorist organizations.

\section{Ethical Combat against Terrorists}

The Bush administration's unlawful actions during questioning, trialing and sentencing the terror suspects received serious public reaction and they have raised suspicions about loyalty of the United States to the values such as rule of law and human rights. The legitimate combat of the United States against terrorists, which started after the catastrophic September 11 attacks, has become disputable issue in terms of ethics and law because of these misappropriate actions. This caused international society to question their consent toward actions of the United States concerning the combat against terrorists. As Gramsci notes, the supremacy of a group will be called as hegemony if it exercises intellectual and moral leadership over other groups. No group or state can maintain its supremacy without gaining legitimacy for its attitudes. ${ }^{44}$ Similar to Gramsci's opinion, Cox argues that a dominant state creates an order based on a broad measure of consent in order to become hegemon ${ }^{45}$. Therefore, President Obama were required to make an effort to achieve consents of other states toward actions of the United States concerning the combat against terrorism. Obama claimed that the United States is required to adopt an ethic and cooperative fighting method against terrorists, which are conforming the values and principles that underlie in the foundation of the United States. ${ }^{46}$ Obama's reaction to this issue has both ethical and strategic characteristic ${ }^{47}$ because adopting policies that would gain support of the international society would increase victory chance in this war. Consequently, American hegemony would have developed its strength in both force and consent dimensions once again.

At this point, the prison in Guantanamo where the terrorist suspects have been held has come to the fore frequently. The detained suspects have been held at the prison for long years without any trial and they incurred all sorts of torture and misbehave. ${ }^{48}$ This situation has taken serious critics from both American and international society since it was against rule of law and human rights promoted by the US in order to ensure that international society to embrace them. As Obama realized this reality, just after his election to presidency, he took an action for the closure of the facility within a year by issuing the Executive Order 13492 on 22 January 2009. ${ }^{49}$ Nevertheless, the congress fiercely opposed this plan and rejected to finance the transportation of the prisoners from Guantanamo to the US soil, because the issue of closure of the Guantanamo detention facility brought up series of legislative and security problems, such as how to prosecute them in the US, and which legislation system to execute, and whether released prisoners would constitute a security risk for the US?

The Executive Order 13492 opened the way to prosecute Guantanamo prisoners in the Federal American Courts as well, if valid evidences exist. However, in spite of all that long time passed, only one prisoner, Ahmed Ghailani, proceeded to the court and trialed through this 
legislation; then, the Congress prohibited transfer of other prisoners since January 2011. Aforementioned order opened way to transfer Guantanamo prisoners to their home countries or a third country in a manner consistent with law, national security and foreign policy interests of the United States. ${ }^{50}$ The second path was followed when transfer of Guantanamo prisoners to the United States was not possible. The very same order required organization of a Guantanamo Review Task Force to carry out official review concerning which prisoners to be prosecuted and | 48 which courts were authorized for trials. ${ }^{51}$ President Obama's efforts concerning Guantanamo continued, and he signed a Defense Bill in December 2013, which facilitated transfer of Guantanamo prisoners to the third countries and which accelerated closure of the detainment center. ${ }^{52}$ As Obama has been aware that it was rather hard to close Guantanamo facility because of the obstacles that he has faced since the time he was elected, he both has continued to spend effort to overcome these issues and has strived to finalize the war in Afghanistan on the account that this will facilitate closure of the detention center.

Besides, the Obama administration prohibited secret prisons of CIA, which were established out of the US soils and not subject to US legislation. Moreover, he cancelled legal memorandums on interrogation policy issued by the Bush administration, and he ordered that all prisoners were subject to protection recognized by the Geneva Convention. He banned application of all advanced interrogation methods, especially waterboarding which causes a prisoner to experience feeling of drowning. ${ }^{53}$ Furthermore, President Obama has amended the Military Commissions Act passed by the Bush administration in 2006, accordingly submission of evidences whose certainty cannot be proved was limited..$^{54}$

Based on all these, the Obama administration's positive steps to carry out an ethical combat against terrorist organizations has repaired legitimacy of the combat against terrorist organizations, gained support of the international society, and thus strengthened American hegemony. However, the numbers of negative processes carried out in the Bush period continued in the Obama presidency as well. The most significant of these is that the unfavorable detention conditions in the Guantanamo facility, whose closure was prevented by the Congress, have not been corrected yet. ${ }^{55}$ Additionally, although transfer of Guantanamo prisoners to their home countries or a third country was allowed by the Executive Order 13492, it is not for sure that there will be fair investigation or prosecution process waiting for them in some countries whose democracy and human right culture have not developed.

Torture has been still existing practice as an interrogation method, because there were several inconsistencies in Obama's policy concerning advanced interrogation methods. For instance, the Guantanamo Review Task Force established with the Executive Order 13492 was authorized to suggest interrogation methods to the CIA, which would go beyond these limits for Guantanamo prisoners. Moreover, an interrogation center where operations are secret and not exposed to the inspection of International Red Cross Committee was still in use within the framework of the Joint Special Operations Command operating under the Department of Defense. ${ }^{56}$ The Obama administration objected to foundation of a truth commission, which would inspect whether torture ban is conformed, or not. The administration did not agreed with the article, which dictates that torture allegations are subject to punitive investigation as it was in the United Nations Convention Against Torture. Accordingly, the Obama administration did not carried out any investigation concerning allegations about tortures in Guantanamo facility, and no any official was held responsible for the tortures carried out in the past. ${ }^{57}$ In case President Obama takes more determined steps regarding carrying out an ethical combat against terrorist organizations due to the convenient environment of his second presidency, policies in other various areas will receive stronger support from the American and international society, and the American hegemony will thus be more strengthened. 


\section{Steps Taken for Democracy Promotion}

Democracy promotion has been viewed as a mission to be accomplished in its foreign policy since foundation of the United States. As an important chapter of the US foreign policy for each US President, this mission had significant place for President Obama as well. However, the significance level of this task within the foreign policy has varied during presidency periods in the US history. Because of the problems caused by policies of the G.W. Bush administration concerning democracy promotion, Obama followed a moderate policy.

Afterwards of the September 11 attacks, the Bush administration adopted an opinion that the most effective way to remove terrorism threat completely was to flourish democratic organizations and to open channels for societies to express their demands. In this regard, the administration associated terrorism threat with anti-democratic states seen as sources of this threat, and they put forward the opinion of democracy promotion across the Islam World. ${ }^{58}$ However, forcing those countries for democracy and targeting administrations of countries resisting this process, changing regimes through military actions, as it was seen sample of Iraq, received great reaction from both Islamic and other countries. While there was no pressure on non-democratic regimes that are allies of the United States, pushing some anti-American regimes for democracy and making them target exposed an impression that the mission of democracy promotion lost its main principle, and this was utilized as a mean to reach hidden purposes. ${ }^{59}$ This situation reduced the success chance of the efforts for democracy promotion and shadowed persuasiveness of the mission of the United States to promote democratic values good for all humanity. Although it was expected that mission of promoting democracy would reduce radical movements and enable foundation of democratic peaceful states, on the contrary, it has turned into a policy, which has weakened the American hegemony.

Obama believes that democratic political systems respecting human rights act more peaceful, and long-term security and welfare of the United States relies on expansion of these values and they can achieve their national interests more conveniently in a democratic world ${ }^{60}$ However, the administration was careful about following a low-profile policy concerning democracy promotion ${ }^{61}$ and conducting this mission without giving harm to the American hegemony because of the damaging effects of the regime replacement actions conducted in the Bush period. The Obama administration also paid attention to have consent of the majority of the international society for the actions performed under the framework of the democracy promotion mission. In this context, although the United States declared that it would continue to defend the rights of nations all around the world, the administration underlined the falsity of imposing democracy from the outside since they were respecting their right to choose the right path that is appropriate to their unique culture and tradition according to their political developments. ${ }^{62}$ This expression can be interpreted as the Obama administration admitted that Bush administration's policy concerning democracy promotion has several mistakes.

Similar to this general approach, the Obama administration decreased the weight of policy for democracy promotion, which they provide to destroy the public support behind the terrorism. In his State of the Union speech given in the very first month of the presidency in 2009, Obama stated that they need to be alerted about supporting liberal democratic values to overcome radicalism. ${ }^{63}$ Nevertheless, while mentioning both combat against terrorist organizations and democracy promotion subjects in National Security Strategy in 2010, there was no bold association established between elimination of terrorism threat and democratization. Furthermore, democracy promotion was excluded among targets of war in Afghanistan because the Obama administration, as it was stated in the former pages, limited the target of the war set by the Bush administration as 'building an outstanding democracy in Afghanistan to dry out resources of terrorism, where it is fed ideologically' with the target of 'disrupting, dismantling and defeating Al Qaeda in Afghanistan and Pakistan'. ${ }^{64}$

In terms of the Middle East region where the democracy promotion policies of the Bush period received public reaction, the Obama administration did not exhibit active initiative. For 
example, the primary orientation in Iraq, the first step of the democratization of the Middle East, was establishing security and withdrawing soldiers successfully. The Obama administration removed the democratization dimension from the policy adopted for Iran whose anti-democratic aspect has been put forward frequently in the public arena by the Bush administration, and the emphasis has given to termination of its nuclear activities. Concerning the relationships with other anti-democratic countries in the Middle East, as it has been before, security interests prevailed.

| 50 Accordingly, regarding the United States's Middle East policy, the Obama administration attached more importance to its security and economic interests than democracy promotion. ${ }^{65}$

Although Obama stated in his speeches that they would welcome peaceful administrations with pleasure, as they are elected based on freewill of their societies, and that the US administration would support democratic reforms in the Middle East, the Obama administration preferred to protect its interests rather than democratization during the Arab Spring that fired up in the end of 2010. For instance, during the uprisings against Hosni Mubarak, an American ally, the administration supported Mubarak, and afterwards the collapse of Mubarak, the administration tried to manage this transition through Egyptian Army ${ }^{66}$ Furthermore, the United States did not react against the military coup, which broke out on 3 June 2013, against Mohamed Morsi, who was elected as the candidate of the Muslim Brotherhood on June 30 2012. While Obama was expressing his concerns about the military intervention and stating that the democratic order must be resumed as soon as possible; he avoided mentioning about Morsi must be returned to his position. ${ }^{67}$ The Obama administration spent great effort to maintain survival of oppressing regimes that were allies of the Washington such as Tunisia, Bahrain and Yemen as well. ${ }^{68}$

The most important reason for the Obama administration to maintain low profile concerning democracy promotion, one of the three elements that compose vision for war on terrorism, is that this mission one of the resources of the American soft power was functioning in the opposite way because of the misappropriate actions of the Bush administration. The active democracy promotion policy followed during the Bush administration in the Middle East has almost gained identical meaning with regime change and military intervention. Moreover, the Bush administration set an ambitious plan such as democratization of expanded Middle East territory (consisted of Middle East, North Africa, Caucasia, Central Asia, Afghanistan and Pakistan), but realization of this plan has failed since there was no sufficient support from both this territory and world. On the other hand, this failure weakened the American hegemony. President Obama was in search of consent of international society for actions taken under the framework of this mission by avoiding initiatives that can receive reaction from international society concerning democracy promotion. In addition, for the sake of democracy promotion, the administration avoided to follow policies, which would damage its economic, security and political interests. Thus, Obama strived to strengthen American hegemony in terms of force and consent aspects.

\section{Efforts to Prevent WMD Threat}

After the September 11 attacks, the Bush administration concluded that terrorists would not have accomplished such a destructive attack without support of a state. Then, they emphasized that terrorists and rogue states could cooperate to give damage to their joint enemy of the United States, the rogue states would supply WMD to terrorists and terrorists would organize destructive attacks against the United States or United States's allies by means of these weapons. ${ }^{69}$ Accordingly, in addition to the possibility that rogue states would possess WMD, another possibility emerged such that these weapons would be captured by the terrorist organizations. Therefore, within the framework of the vision for war on terrorism, more effort was required to spent in order to prevent rogue states to possess these weapons. 
Although this relationship established by the Bush administration between terrorist organizations and rogue states based on WMD seemed logical, it was not successful in application. There was no mass destruction weapon found in Iraq, even though a war started against this country based on an allegation that it has these weapons. This situation elevated the worldwide reactions against this war already disputable in terms of political and legal angles. Due to these developments experienced in Iraq, the great majority of states in the world did not adopt Washington's pressure on Iran and the North Korea, states that were declared as parts of axis of evil. Lack of international society's support and frequent military intervention threat hindered having positive results from diplomatic attempts concerning nuclear programs of these states. Accordingly, in 2009, when it comes to the time Bush passed on the presidency, these states achieved substantial advancements in nuclear technology, and this was a situation challenging American hegemony. Besides, the difficulty experienced by Washington having support even from its closest allies in its policies against the threat of WMD was evidencing that the consent given for American hegemony was not strong enough. Therefore, it was required to review the policies against the threat of WMD from top to bottom.

When the President Obama's foreign policy rhetoric is reviewed, it can be observed that terrorists' capability to access WMD was emphasized as frequently as the Bush administration. Obama declared in his both election campaign and during his presidency that the worst threat against the American nation was the situation that terrorists obtain nuclear weapons. ${ }^{70}$ Although the Obama did not directly mention the names of Iran and North Korea, anti-American countries who possess or have chance to possess nuclear weapons, he implied the possibility that they would hand over these weapons to terrorists and was concerned about realization of this possibility. As WMD threat was so great that it threatens not only United States and its allies but also all states, it was a necessity for the United States to be successful in eliminating this threat for strengthening international security. In Cox's opinion mentioned in previous pages, ${ }^{71}$ hegemon state has responsibility for protecting international peace and security. If the hegemon state was not able to fulfill its responsibility for the maintenance of international order, other states would question this state's capability to act as a hegemon. Therefore, the United States as a hegemon must spend more effort to prevent terrorists and rogue states from threatening international security and stability with WMDs.

President Obama took an action to prevent WMD threat to damage American hegemony. The Obama administration's approach toward prevention of WMD threat was based on an ideal world without nuclear weapons. In this context, as Obama stated in his Prague speech in 5 April 2009 that they will downsize the nuclear weapon's role in the American security strategies since the Cold War mentality disappeared and that they will strive to persuade other countries to do the same. Obama adopted a strategy with three pillars to create a world without nuclear weapons. The first pillar of this strategy is that reduction in number of nuclear weapons in the inventories of the prominent nuclear countries, ${ }^{72}$ which enables other countries to take further step for nuclear disarmament. In order to implement this strategy, the Strategic Arms Reduction Treaty (The New START) that projects the reduction in number of deployed nuclear warheads in the United States and Russia within 7 years was signed on 8 April 2010. Obama, in his second presidency period, took a step to sign a new treaty with Russia to reduce nuclear warheads by $1 / 3 .{ }^{73}$ Obama has been also endeavoring for approval of the Comprehensive Nuclear Test Ban Treaty, which was not ratified by the Senate though it was signed in $1996 .^{74}$ Besides these efforts, the Obama administration stated in the Nuclear Posture Review Report issued in April 2010 that the United States would not use nuclear weapons unless the country does not incur a nuclear attack. ${ }^{75}$

The second pillar of the strategy adopted by Obama is preventing states that have not any nuclear weapon yet to have access to these weapons. ${ }^{76}$ The first thing comes to the mind regarding this subject is the issue concerning nuclear programs of Iran and North Korea. The Obama administration followed an active diplomacy to bring resolution to Iran's nuclear program after October 2009. Since there has not been a positive result out of these talks, the administration put the United Nations (UN) Security Council in charge and ensured that the Council has adopted Resolution 1929 in June 2010. ${ }^{77}$ Additionally, upon threat of the Tehran administration in 2012 
concerning closure of the Hormuz Strait to interrupt the world oil trade, Obama signaled that he would include military intervention choice among his options for preventing Iran to take adverse actions to affect international security and economic stability. ${ }^{78}$ Along with these developments, Obama did not give up on diplomacy option and finally come to an agreement with Iran by 24 November, 2013. According to this agreement, Iran would not enrich uranium more than 5\%, and it would facilitate UN's weapon inspections. In return, the sanctions applied to this country would |52 be loosened.79 About controlling Iran's nuclear activities, it can be said that the Obama administration achieved concrete results because they found a solution for significant problem challenging American hegemony for the first time as a result of the negotiations that have been conducted since end of 2003.

The Obama administration was not able to show the same success concerning nuclear activities of the North Korea. The Obama administration has carried out frequent meetings at the senior level in order to resume Six Party Talks with the administration at Pyongyang, which was interrupted in 2008, but this was not achieved. ${ }^{80}$ The North Korea agreed to cease uraniumenriching activities of the Yongbyon Facility in February 2012 and to apply moratorium on nuclear and long-range missile tests. However, another nuclear test carried out by the Pyongyang administration in February 2013 and the Yongbyon Facility resumed its activity, that is, the Obama administration lost its sole tangible achievement. Since the Obama administration was not able resolve issues related with the nuclear activities of the North Korea through diplomatic ways, they answered Pyongyang's steps elevating the tension with strong reaction. In this context, several sanctions commenced against North Korea in both 2010 and 2011. Besides, Obama ensured that the UN Security Council took sanctions with Resolutions 1874 (June 2009), 2087 (January 2013) and 2094 (March 2013). The US showed of force to North Korea through extensive military exercises conducted in cooperation with South Korea in July 2010 and February $2011 .{ }^{81}$ As it is clear, the Obama administration failed in preventing nuclear activities of North Korea in spite of numbers of initiatives taken since the time Obama came to power. Additionally, when it is considered that the relationship with North Korea has tensed further since 17 December 2011, after the presidency of Kim Jong-Un, it would not be wrong to conclude that nuclear activities of the North Korea would continue to be a challenge for American hegemony.

While the Obama administration was attempting to prevent new nuclear countries to emerge, on the other hand they tried to prevent passing these weapons in the possession of terrorists. To that end, the Nuclear Security Summit organization took place with the participation of more than 50 countries upon initiatives of the United States in Washington on April 2010, in Seoul on March 2012, and in Hague on March 2014. In these summits organized in every two years, participant countries guaranteed to take solid steps to secure all nuclear materials across the world properly. ${ }^{82}$ However, because there is no consensus among countries about which nuclear materials were not being deposited safely at that moment, the purpose of securing all nuclear materials in the world has not achieved yet. ${ }^{83}$ Therefore, the Obama administration has not been able to remove concerns that terrorist organizations could have access to these nuclear substances.

The third and final pillar of the Obama's nuclear disarmament strategy is to establish a missile defense system against nuclear threat toward the United States and/or one of its allies. ${ }^{84}$ Against an intercontinental missile threat toward the United States, the interceptor missiles were deployed in Alaska and California. Additionally, Iran and North Korea has no intercontinental ballistic missiles that can hit the US soils yet. Therefore, President Obama claimed that their European allies were in danger indeed. The Obama administration inactivated missile defense plan of the Bush administration and instead, they suggested European Phased Adaptive Approach (EPAA). The EPAA was to be realized under the NATO body to protect European allies against the short and medium-range missile threat from Iran. It was envisaged that application of the EPAA will be in four phases until 2020 and required amendments on the project would be performed according to the direction of the nuclear threat perceived from Iran. ${ }^{85}$ The missile defense project, which came to the agenda of the each president since President Ronald Reagan has not been accomplished because of the opposition of Russia. On the other hand, the Obama administration assured that this system was against Iran. In addition, the administration ensured 
that the project was based on multi-lateral platform of the NATO organization and suggested cooperation concerning the missile defense system between NATO and Russia ${ }^{86}$ in order to moderate oppositions and put this project into effect, which has been planned for 25 years. This project is a significant success in terms of prevention of threat caused by the nuclear activities of Iran since it created substantial pressure over this country.

As this it is clear from all these above, prevention of WMD has been an issue that kept President Obama busy intensively during both his first and second presidencies due to the adverse inheritance left by the Bush administration. The primary interest of the Obama administration concerning this subject was oriented on preventing anti-American states such as Iran and North Korea to possess nuclear weapons and to deliver these weapons to terrorist organizations. The Obama thought that American hegemony would face a serious threat in case these states obtain nuclear weapons, and carried out an active diplomacy in order to ensure to keep nuclear programs of these countries under control. The administration has not been successful at preventing nuclear activities of North Korea, but for the first time they have succeeded on their efforts that have been spent for more than 10 years at controlling nuclear activities of Iran by means of the UN inspection, which was seen as an urgent issue. Besides, the administration actualized the EPAA to provide protection to its European allies against the nuclear threat from Iran. In this process, the Obama administration believed that the threat of WMD could only be avoided through international cooperation. In this regard, the administration attached importance both to act in a concert with its European allies and to obtain opportunity to cooperate with Russia, a major nuclear power. Actualization of the missile defense system was debated for 25 years during this period, and the agreement taking Iran's nuclear activities under control were result of this multilateral cooperation. Accordingly, President Obama has made progress in strengthening American hegemony that weakened during the Bush administration by gaining support of the international society for his policies concerning prevention of extension of WMD.

\section{Conclusion}

The war on terrorism that shaped the foreign policy and national security structuring, tools and polies of the United States in the post-September 11 period has arisen as vision that could reconstruct American hegemony. Because of the significance of the war on terrorism in terms of the American foreign policy, the Obama administration did not abandoned vision for war on terrorism, and they included basic elements of this vision into the foreign policy. However, due to the actions of the Bush administration, which weakened the American hegemony, the Obama administration aimed to carry out vision for war on terrorism through more rational policies, and thus, to reverse the weakening tendency of the American hegemony. In other words, the administration attempted to develop America's muscle through policies supported by the international society that strengthening American hegemony in terms of both force and consent aspects.

First of all, the Obama administration aimed to carry out more effective combat against terrorist organization by trying to include Taliban into Afghanistan's political life; establishing pressure with additional American soldiers sent to there; targeting Al-Qaeda's organization in Pakistan; and assassinating Al-Qaeda leader Osama bin Laden. Moreover, the administration attempted to restore legal and moral legitimacy of the combat against terrorist organizations through initiatives to close the Guantanamo Detention Center, and banning torture and advanced interrogation methods. Concerning the mission of democracy promotion, the administration tried to earn consent of international society by avoiding actions that would attract their negative reaction. In addition, for the sake of democracy promotion, the administration avoided to adopt policies that would damage economic, security and political interests of the United States. Accordingly, the Obama administration tried to conduct mission of democracy promotion without giving damage to the American hegemony. Finally, the Obama administration has taken following steps to eliminate the threat of the WMD toward the United States and its allies: they executed the 
New START with Russia; put an effort for ratification of the Comprehensive Nuclear Test Ban Treaty; carried out multi-lateral diplomacy to take nuclear activities of Iran and North Korea under control; pioneered international cooperation to ensure safety of nuclear materials; and enabled foundation of a missile defense system against a nuclear attack possibility toward Europe. The administration acted in cooperation with its allies for successful results.

|54 During the 6-year presidency period, although it is not possible to say that president Obama was successful at reaching the targets that he determined concerning combat against terrorist organizations, democracy promotion, and prevention of threat of WMD, it is possible to claim that he achieved better results than the Bush administration regarding the same policies. The Al-Qaeda terror organization was damaged seriously through military operations conducted in Afghanistan and Pakistan; and the leader of the organization was assassinated after ten years of effort. The perception that there is a more legitimate combat against terrorist organizations in terms of legal and ethical perspectives at the international level prevailed during his presidency. The United States is not considered as a country imposing democracy to the Islamic countries anymore. The administration acquired tangible success concerning controlling Iran's nuclear activities. The efforts in prevention of expansion of WMD continued in a multi-lateral way with the participation of global powers such as European allies, Russia and China. Accordingly, significant acquisitions have been gained during the Obama administration concerning the solutions of issues faced by the United States. Furthermore, because the administration was attentive to act in a multi-lateral way in solution of these problems, it was easier to obtain support of the international society for its foreign policy. Therefore, there is now stronger American hegemony based on comprehensive consent.

This situation does not mean that the Obama administration was fully successful at strengthening consent aspect of the American hegemony, which had weakened in the post-cold war period. For instance, while the Guantanamo Facility has been open, the detention conditions of the prisoners in this facility have still been unacceptable. Torture in the interrogation process has not been completely abandoned. Accordingly, political and legal legitimacy of the United States's combat against terrorist organizations have not been satisfied yet. Along with the Arab Spring, while the Obama administration was trying to remove the administrations in Libya and Syria based on accusations of being anti-democratic, they supported other anti-democratic regimes in Tunisia, Egypt, Bahrain, Yemen and Saudi Arabia. Consequently, this attitude gave an impression in the Muslim world that there is not major difference between approaches of the Obama administration and the Bush administration toward the democracy promotion. All of these are the factors weakening the international society's consent at some scale toward the policies of the Obama administration. In terms of the threat of the WMD, the Obama administration has gained successful results because they managed the diplomacy process including global actors such as Russia, China and the EU. However, it was still hard to reach a consensus on what should be done among these actors when the diplomatic process deadlocks (imposing economic sanctions, using military force etc. As a result, although American hegemony earned greater consent in the Obama period compared to the Bush period, the US still has trouble to gain consent of the international society for its hegemon position. Accordingly, the United States, as a hegemon power, has not succeed to achieve the legitimacy status, which was experienced during the Cold War within the axis of struggle with communism, in the Western Block during the Obama period as well.

Furthermore, it is not possible to say that all challenges to the American hegemony have totally disappeared. The order and stability in Afghanistan has not been totally restored; the actions to neutralize Al-Qaeda and Taliban have not succeeded. Uprising process initiated with the Arab Spring continues to threat American interest in the Middle East. Especially, civil war in Syria has come to an uncontrollable point, and Al-Qaeda has gained prominence as an effective actor. The Sunni resistance in Iraq resumed and The Islamic State of Iraq And Syria (ISIS) has emerged as a serious threat. There has not been tangible result reached yet concerning taking nuclear activities of North Korea under control. The threat of Iran against the United States, Israel and Gulf countries still subsist. As it is clear, the United States is facing with serious issues, which 
pose risk in terms of maintaining future of the United States's hegemon status. Therefore, concerning the solution of these issues, the efficiency of the policies followed by Obama and his successors and the international consent toward these policies will determine the future status of the American hegemony.

Notes

1 G. John Ikenberry, After Victory: Institutions, Strategic Restraint, and the Building of Order After Major Wars (Princeton: Princeton University Press, 2001), 163-166; Sandra Destradi, "Regional Powers and Their Strategies: Empire, Hegemony, and Leadership," Review of International Studies 36 (October 2010): 917918.

2 Perry Anderson, "Force and Consent," New Left Review 17 (September-October 2002): 6-7.

3 Antonio Gramsci, Hapishane Defterleri: Tarih, Politika, Felsefe ve Kültür Sorunlarl Üzerine Seçme Metinler, trans. Kenan Somer (Istanbul: Onur Yayınlar1, 1986), 14,73-74.

4 Quoted by Benedetto Fontana, "Gramsci on Politics and State," Journal of Classical Sociology 2 (July 2002): 159.

5 Destradi, "Regional Powers and Their Strategies," 916-917.

6 Robert W. Cox, "Gramsci, Hegemony and International Relations: An Essay in Method," Millenium: Journal of International Studies 12 (June 1983): 170-171.

7 Robert W. Cox, "Beyond Empire and Terror: Critical Reflections on the Political Economy of World Order," New Political Economy 9 (September 2004): 310.

8 Barry Buzan, "Will the 'Global War on Terrorism' be the New Cold War?," International Affairs 82 (November 2006): 1101.

9 Deepak Tripathi, Overcoming the Bush Legacy in Iraq and Afghanistan (Washington, D.C.: Potomac Books, 2010), 23-25.

10 Richard Jackson, "Culture, Identity and Hegemony: Continuity and (the Lack of) Change in US Counterterrorism Policy from Bush to Obama," International Politics 48 (March-May 2011): 394-406.

11 The United States is of the opinion that these values are for good of humanity and all societies are subject to the right to live with these values. Therefore, the United States supports that these values are to be adopted across the world.

12 David Campbell, Writing Security: United States Foreign Policy and the Politics of Identity (Minneapolis: University of Minnesota Press, 1998), 9,91-92.

13 The expression of 'combat against terrorist organizations' should not be confused with 'war on terrorism'. Beside the fact that 'the combat against the terrorist organizations' is the primary subject, which emerges 'the vision for war on terrorism', this is one of the three elements consisting of this vision. As is seen in the further sections, the vision for war on terrorism has involved democracy promotion and prevention of WMD by going beyond being a policy targeting terrorist organizations. Accordingly, the expression of 'war on terrorism' means more than 'combat against terrorist organizations' within the scope of the present study.

14 “Barack Obama's Inaugural Address,” New York Times, January 20, 2009.

15 "Obama's Speech at Woodrow Wilson Center," August 1, 2007, accessed May 18, 2013, http://www.cfr.org/elections/obamas-speech-woodrow-wilson-center/p13974.

16 "Transcript of Obama Remarks on Airline Security and Terror Watch Lists," December 28, 2009, accessed May 18, 2013, http://voices.washingtonpost.com/44/2009/12/obama-remarks-on-airlinesecur.html.

17 James M. Lindsay, "George W. Bush, Barack Obama and the Future of US Global Leadership," International Affairs 87 (July 2011): 770.

18 Douglas Kellner, From 9/11 to Terror War: The Dangers of the Bush Legacy (Lanham, MD: Rowman\&Littlefield, 2003), 2.

19 Juan Cole, "Pakistan and Afghanistan: Beyond the Taliban," Political Science Quarterly 124 (Summer 2009): 221-222.

20 Peter Beinart, “Obama Shrinks the War on Terrorism,” Time, December 7, 2009, accessed May 18, 2013, http://www.time.com/time/magazine/article/0,9171,1945337,00.html.

21 Zbigniew Brzezinski, "Major Foreign Policy Challenges for the Next US President," International Affairs 85 (January 2009): 59.

${ }^{22}$ Lindsay, "George W. Bush, Barack Obama and," 765-770.

23 About this subject, see: Dana H. Allin, "The Atlantic Crisis of Confidence," International Affairs 80 (July 2004): 649-663; Kellner, From 9/11 to Terror War, 3; Geir Lundestad, "The United States and 
Western Europe: Transatlantic Drift or Just Another American-European Crisis?," (Florence: European University Institute, EUI Working Papers in Political and Social Sciences, No: 12, 2004).

24 Kellner, From 9/11 to Terror War, 3-5.

25 About this subject, see: James MacHaffie, "The Potential for a China-Russia Military Alliance Explored”, Alternatives: Turkish Journal of International Relations 10 (Summer-Fall 2011): 21-44.

| $56 \quad{ }^{26}$ Lindsay, "George W. Bush, Barack Obama and," 765-766. A Two Year Assessment ed. John Davis (New York: Palgrave Macmillan, 2011), 168.

28 Barack Obama, "Renewing American Leadership," Foreign Affairs 86 (July-August 2007), accessed May 18, 2013, http://www.attiaspace.com/Assignments/obama.pdf.

29 Robert Singh, Barack Obama's Post-American Foreign Policy: The Limits of Engagement (London: Bloomsbury Academic, 2012), accessed $\quad$ May $18, \quad 2013$ https://www.bloomsburycollections.com/book/barack-obamas-post-american-foreign-policy-the-limits-ofengagement/.

30 Cox, "Gramsci, Hegemony and International Relations," 171.

31 Beinart, "Obama Shrinks"; Obama, "Renewing American Leadership".

32 "Remarks by the President on a New Strategy for Afghanistan and Pakistan," March 27, 2009, accessed May 18, 2013, http://www.whitehouse.gov/the_press_office/Remarks-by-the-President-on-a-New-Strategyfor-Afghanistan-and-Pakistan.

$33 \mathrm{Oz}$ Hassan and Andrew Hammond, "The Rise and Fall of American's Freedom Agenda in Afghanistan: Counter-Terrorism, Nation-Building and Democracy," The International Journal of Human Rights 15 (April 2011): 544.

34 "Remarks by the President on a New Strategy for Afghanistan and Pakistan"; "Remarks by the President in Address to the Nation on the Way Forward in Afghanistan and Pakistan," December 1, 2009, accessed May 18, 2013, http://www.whitehouse.gov/the-press-office/remarks-president-address-nation-way-forwardafghanistan-and-pakistan.

35 Boryana Aleksandrova, "The Global War on Terrorism in the Middle East - Epistemological Questions for Peace and Conflict Studies", Alternatives: Turkish Journal of International Relations 12 (Summer 2013): 51. About statements of the American and Afghan authorities concerning this subject, see: Anatol Lieven and Maleeha Lodhi, "Bring in the Taliban," The New York Times, April 22, 2011; Beinart, "Obama Shrinks"; Zabihullah Noori, "Reconciliation with Taliban: An Impossible Plan," accessed October 10, 2012, http://www.eurasiareview.com/10102012-reconciliation-with-taliban-an-impossible-plan-analysis/. 36 Beinart, "Obama Shrinks".

37 "Remarks by the President in Address to the Nation on the Way Forward in Afghanistan and Pakistan".

38 Susan B. Epstein and K. Alan Kronstadt, "Pakistan: U.S. Foreign Assistance," CRS Report for Congres, R41856 (2012), 6.

39 Trevor McCrisken, “Ten Years on: Obama's War on Terrorism in Rhetoric and Practice,” International Affairs 87 (July 2011): 793-794.

40 Dana Allin, "Chapter Two: US Policy and Afghanistan," Adelphi Series 51 (425-426, 2011): 47-51.

41 Ernesto Londoño, Karen DeYoung and Greg Miller, "Afghanistan Gains will be Lost Quickly After Drawdown, U.S. Intelligence Estimate Warns," The Washington Post, December 28, 2013.

42 V. Sergeyev, "The USA in Afghanistan," International Affairs: A Russian Journal of World Politics, Diplomacy and International Relations 58 (3, 2012): 64-65.

43 Michael Pizzi, "US-Taliban Prisoner Swap Inspires Tentative Hopes for Afghan Peace,” accessed June 2, 2014, http://america.aljazeera.com/articles/2014/6/2/afghanistan-peacetalks.html.

44 Gramsci, Hapishane Defterleri, 15, 73-74.

45 Robert W. Cox, Production, Power and World Order: Social Forces in Making of History (New York: Columbia University Press, 1987), 7.

46 McCrisken, "Ten Years on," 782.

47 Timothy J. Lynch, "A Change of Leaders is the Joy of Fools': Bush, Obama and Continuity in American Foreign Policy," (Canberra: Australian Political Science Association, September 27, 2011).

48 About this subject, see: Kellner, From 9/11 to Terror War, 178.

49 “Executive Order 13492 of January 22, 2009," Federal Register 74 (January 26, 2009).

50 In the Obama period, 88 prisoners have been either transferred to another country or released. Will Carless, "These are the 5 Guantanamo Detainees Who Might be Moving to Uruguay," 2014, accessed March 28, 2014, http://www.globalpost.com/dispatch/news/regions/americas/140327/guantanamodetainees-transferred-uruguay.

51 "Executive Order 13492 of January 22, 2009". 
52 "Obama Defense Bill to Facilitate Transfer of Prisoners from Gitmo," 2013, accessed December 23, 2013, http://rt.com/usa/obama-defense-budget-guantanamo-862/.

53 Hilde Eliassen Restad, "The War on Terror from Bush to Obama: On Power and Path Dependency," (Oslo: Norwegian Institute of International Affairs Working Paper, No: 798, 2012) 27.

54 Jonathan Masters, "Closing Guantanamo?," November 9, 2011, accessed May 18, http://www.cfr.org/terrorism-and-the-law/closing-guantanamo/p18525.

55 Tung Yin, “'Anything but Bush?': The Obama Administration and Guantanamo Bay,” Harvard Journal of Law \& Public Policy 34 (March 2011): 477; Jerry Votava, "Guantanamo Detainees Face Harsh Conditions, Hunger Strike: Defense Lawyers," accessed March 7, 2013, http://jurist.org/paperchase/2013/03/guantanamo-detainees-face-harsh-conditions-protests-include-hungerstrike-defense-lawyers.php.

56 Richard M. Pious, "Prerogative Power in the Obama Administration: Continuity and Change in the War on Terrorism," Presidential Studies Quarterly 41 (June 2011): 269.

57 Restad, "The War on Terror from Bush to Obama," 35-36.

58 Risa Brooks, "Researching Democracy and Terrorism: How Political Access Affects Militant Activity," Security Studies 18 (December 2009): 756-758. For the Bush administration's initiatives concerning this subject, see: Muhammad Azam and Sagheer Ahmad Khan, "American Democracy Promotion in the Arabian Gulf", Alternatives: Turkish Journal of International Relations 11 (Spring 2012): 85-96.

59 Hussein Banai, "Democratic Solidarity Rethinking Democracy Promotion in the New Middle East," Security Dialogue 44 (October-December 2013): 421-422; Nicolas Bouchet,"The Democracy Tradition in US Foreign Policy and the Obama Presidency," International Affairs 89 (January 2013): 31-32.

60 National Security Strategy, (Washington, D.C.: The White House, 2010), 35-37.

61 Banai, "Democratic Solidarity," 422-423.

62 Barack Obama, "Remarks by the President to the United Nations General Assembly," 23 September 2009, accessed April 13, 2014, http://www.whitehouse.gov/the_press_office/Remarks-by-the-President-tothe-United-Nations-General-Assembly/.

63 "Remarks of President Barack Obama," 24 February 2009, accessed May 18, 2013, http://www.whitehouse.gov/the-press-office/remarks-president-barack-obama-address-joint-session-

congress.

64 "Remarks by the President on a New Strategy for Afghanistan and Pakistan".

65 Bouchet, "The Democracy Tradition," 49-50.

66 Bouchet, "The Democracy Tradition," 50.

67 Martin Beck, "The July 2013 Military Coup in Egypt: One Normative Clarification and Some Empirical Issues," (Odense: Center for Mellemoststudier, 2013), accessed June 17, 2014, http://static.sdu.dk/mediafiles/A/D/3/\%7BAD3D4AD4-2CE1-4C46-90ED-

81FDD82DF7B3\%7DMB0913.pdf.

68 For more detailed information concerning the US's policy toward the Arab Spring, see: Daniel Byman, "Explaining the Western Response to the Arab Spring," Journal of Strategic Studies 36 (April 2013): 289320.

69 The National Security Strategy of the United States of America, (Washington, D.C.: The White House, 2002), 13-14.

70 The National Security Strategy of the United States of America; "Transcript of First Presidential Debate," October 14, 2008, accessed May 18, 2013, http:/edition.cnn.com/2008/POLITICS/09/26/debate.mississippi.transcript/; "Remarks by the President in State of the Union Address," January 27, 2010, accessed May 18, 2013, http://www.whitehouse.gov/thepress-office/remarks-president-state-union-address.

71 Cox, "Gramsci, Hegemony and International Relations," 171.

72 "Remarks by President Barack Obama," April 5, 2009, accessed May 18, 2013, http://www.whitehouse.gov/the_press_office/Remarks-By-President-Barack-Obama-In-Prague-As-

Delivered.

73 Anna Peczeli, "Negotiated Cuts: A New Nuclear Weapons Treaty is not the Only Option," 2014, accessed January 27, 2014, http://thebulletin.org/negotiated-cuts-new-nuclear-weapons-treaty-not-onlyoption.

74 For the Obama's initiatives concerning this subject, see: Aiden Warren, The Obama Administration's Nuclear Weapon Strategy: The Promises of Prague (Milton Park: Routledge, 2014), 5; Rachel Oswald, "Obama Official Optimistic on CTBT, New Nuke Cuts in Second Term," accessed March 27, 2013, http://www.nti.org/gsn/article/obama-official-optimistic-both-ctbt-and-new-arms-cuts-russia-second-term/.

75 Nuclear Posture Review Report, (Washington, DC: US Department of Defense, 2010).

76 "Remarks by President Barack Obama," 5 April 2009. 
77 Kenneth Katzman, "Iran Sanctions," CRS Report for Congres, No. RS20871, April 26, 2012, 4,28; "Timeline: Iranian Nuclear Dispute," accessed June 17, 2012, http://www.reuters.com/article/2012/06/17/us-iran-nuclear-talks-events-idUSBRE85G0QD20120617.

78 Michael Singh, "To Keep the Peace with Iran, Threaten to Strike," The Washington Quarterly 35 (Spring 2012): 58-61.

| 58 "Joint Plan of Action," Geneva, 2013, accessed November 24, 2013, http://eeas.europa.eu/statements/docs/2013/131124_03_en.pdf.

80 For the efforts in this way, see: Leszek Buszynski, Negotiating with North Korea: The Six Party Talks and the Nuclear Issue (Milton Park: Routledge, 2013), 173-176.

81 "Chronology of U.S.-North Korean Nuclear and Missile Diplomacy," 2014, accessed July 16, 2014, http://www.armscontrol.org/factsheets/dprkchron.

82 Masashi Nishihara, "The 2012 Seoul Nuclear Security Summit: Accomplishments and Challenges," accessed May 19, 2012, http://www.eastasiaforum.org/2012/05/19/the-2012-seoul-nuclear-security-summitaccomplishments-and-challenges/; Sarah Diehl and Paula Humphrey, "The April 2010 Nuclear Security Summit: One More Step Toward the Mountaintop," April 20, 2010, accessed May 18, 2013, http://www.nti.org/analysis/articles/april-2010-nuclear-security-summit/; Sharon Squassoni, "Outcomes from the 2014 Nuclear Security Summit," accessed March 25, 2014, http://csis.org/publication/outcomes2014-nuclear-security-summit.

83 Squassoni, "Outcomes from the 2014".

84 "Remarks by President Barack Obama," April 5, 2009.

85 Jeffrey Mankoff, "The Politics of US Missile Defence Cooperation with Europe and Russia," International Affairs 88 (March 2012): 337-338.

86 For the cooperation between NATO and Russia about missile defense, see: Talitha Dowds, "The Russia/US/NATO Relationship on Missile Defense," May 19, 2011, accessed July 19, 2014, http://csis.org/blog/russiausnato-relationship-missile-defense. 